\title{
水溶液中における多点相互作用に基づく新機能性超分子の創製
}

\author{
青木 伸
}

\section{Creation of New Supramolecular Chemistry Based on Multiple Interaction in Aqueous Solution}

\author{
Shin AOKI \\ Graduate School of Biomedical Sciences, Hiroshima University, \\ 1-2-3 Kasumi, Minami-ku, Hiroshima 734-8551, Japan
}

(Received June 17, 2002)

\begin{abstract}
Novel supramolecular chemistry of multinuclear zinc(II) complexes in aqueous solution has been created by utilizing multiple interactions with polyanions. We have established reliable and convenient synthetic methods of multidentate macrocyclic polyamines and their zinc (II) complexes and thereby undertook a focused investigation of four topics: 1) efficient inhibition of photo [2+2] cycloaddition of thymidine dimer by dimeric zinc(II) complexes; 2) selective extraction and transport of thymidine nucleotide derivatives from the aqueous phase to the organic phase by lipophilic zinc (II) complexes and selective recognition of thymidine nucleotides by ditopic zinc(II) complexes in aqueous solution; 3 ) supramolecular polyhedrons formed by self-assembly of a trimeric zinc (II) complex with cyanuric acid or trithiocyanuric acid; and 4) a selective fluorescent probe for lanthanide ions such as $\mathrm{Y}^{3+}$ and $\mathrm{La}^{3+}$ based on a double-functionalized ligand with carbamoyl and dansyl groups. This knowledge should afford new methodology for supramolecular chemistry in aqueous solution.
\end{abstract}

Key words — - supramolecular chemistry; multinuclear zinc(II) complexes; aqueous solution

\section{1. はじめに}

水素結合， $\pi-\pi$ スタッキングなどの非共有結合を 用いる分子認識と新機能の開発は，有機化学におけ る重要なテーマの 1 つであるが, 従来その多くは非 水環境で行われてきた. ${ }^{1-6)}$ しかし今後, 環境問題 や生体への適応を考えると，水溶液中における新し い化学の展開が強く望まれる.

12 員環テトラアミン (cyclen) の亜鉛（II）錯体 $1\left(\mathrm{Zn}^{2+}\right.$-cyclen) は, 生理 $\mathrm{pH}$ 水中で種々のアニオ ン（リン酸，チミジン，チオールなど） と配位結合 に基づく複合体を生成する. ${ }^{7-13)}$ 水溶液中の分子認 識と集積体の構築には金属一リガンド配位結合が有 効であり，金属の配位子を様々に修飾することによ つてこれまでにない機能を生み出すことができる. そこで筆者らは,「多核亜鉛錯体とポリアニオン化 合物の協同的多点相互作用によって生成する自己集

広島大学大学院医歯薬学総合研究科（T734-8551 広島 市南区霞 1-2-3)

*本総説は, 平成 13 年度日本薬学会中国四国支部学術 奨励賞の受賞を記念して記述したものである.
積体が, 熱力学的にだけでなく, 速度論的にも安定 化され, 新しい機能をもつ」という仮説を実験的に 証明し, 水溶液中における新たな超分子化学を展開 した（Fig. 1). 本論文では，以下の 4 点について 紹介する.

第 1 に，チミジン誘導体の光損傷反応を制御する 二核亜鉛錯体について述べる. 次に, 抗 HIV 薬で ある AZT の選択的キャリアーの開発とAZT のリ ン酸化体の選択的なレセプター及びキャリアーの開 発への展開を紹介する。第 3 に多核亜鉛錯体を力チ オン性分子ユニットとして用い，ポリアニオン性ユ ニットとの自己集積による超分子多面体の構築につ いて述べる. 最後に, 多官能基の付与による新たな 金属イオン選択性と蛍光特性をもつ光応答センサー の構造と機能について紹介する.

2. 多官能基を有するポリアミン化合物とその金 属錯体の合成

筆者らはまず，塩基性が強く極性が大きい（した がつて水溶性が大きい) ポリアミン誘導体と亜鉛錯 体を簡便にかつ大量に合成する方法を確立してきた 


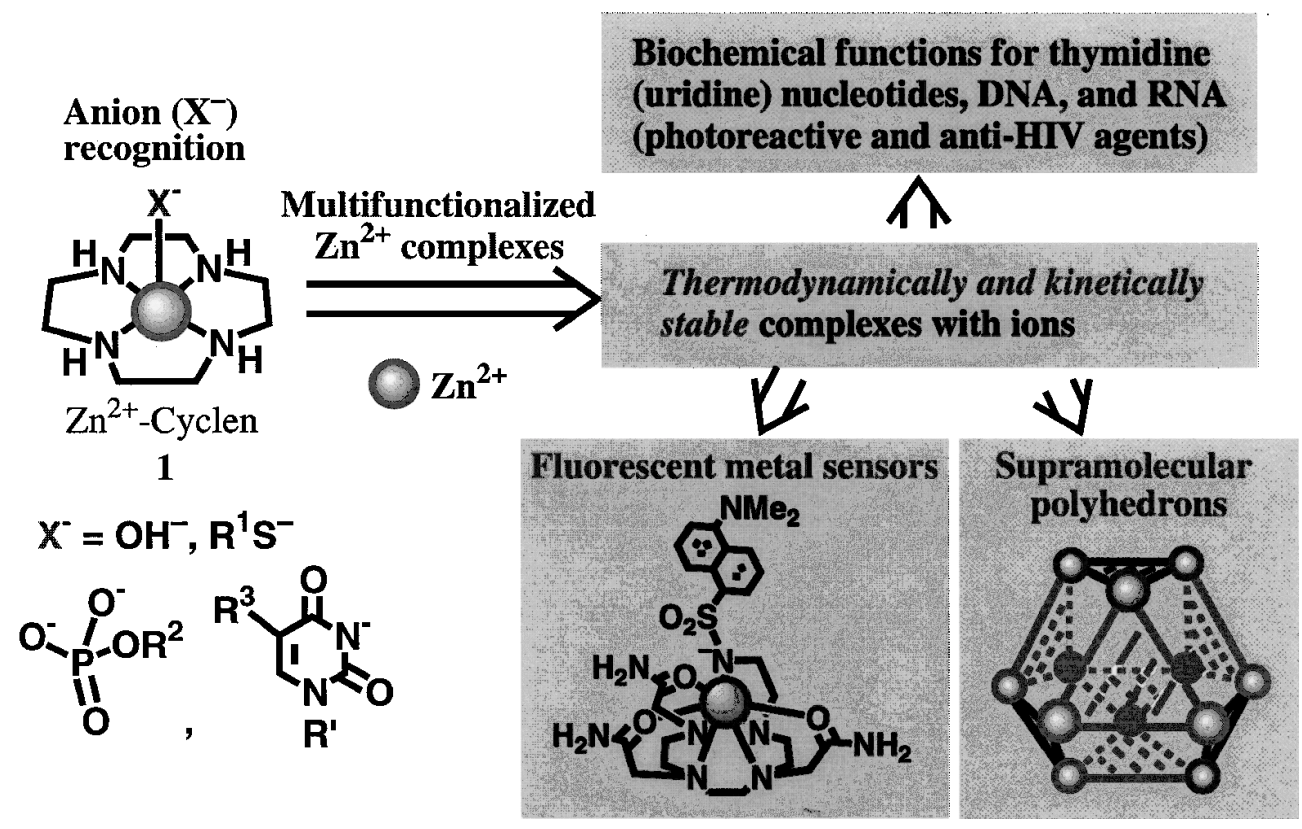

Fig. 1. New Supramolecular Chemistry Based on Multifunctionalized Complexes

(Fig. 2).

まず cyclen の窒素原子の 3 つを保護した 3Boccyclen (2) ${ }^{14)}$ を共通の合成中間体として設定し, 窒 素原子の 1 つに側鎖を導入した単核亜鉛錯体 $3(\mathrm{R}$ $=$ alkyl, aryl など $),{ }^{15-22)} 4\left(m-\mathrm{Zn}_{2} \mathrm{~L}\right)$ や $5\left(p-\mathrm{Zn}_{2} \mathrm{~L}\right)$ などの二核錯体, 三核亜鉛錯体 $6\left(\mathrm{Zn}_{3} \mathrm{~L}\right)^{14)}$ を収率 良く合成することに成功した。次に, Desterux ら によって合成された 2Dep-cyclen (7) ${ }^{23-25)}$ との組み 合わせにより，直列型三核亜鉛錯体 $8(p, p$ $\left.\mathrm{Zn}_{3} \mathrm{~L}\right)^{26-29)}$ 及び四核巠鉛錯体 $9\left(p, p, p-\mathrm{Zn}_{4} \mathrm{~L}\right)^{30)}$ を合 成した。また，2 を Cbz-cyclen (10) へ変換し, ダ ンシルアミド基と 3 つのアセトアミド基をもつ 11 へ変換した. ${ }^{31)}$ さらに 2 と 12 員環トリアミン ([12] $\mathrm{aneN}_{3}$ ) の 2Boc 体 (12) ${ }^{32)}$ を用いてへテロ二核亜鉛 錯体 12 も合成可能である. ${ }^{33)}$

3. 大環状ポリアミン化合物の金属錯体によるア ニオンの認識

$\mathrm{Zn}^{2+}$-cyclen 錯体 1 は DNA（RNA）を構成する 4 つの核酸塩基，アデノシン $(\mathrm{dA})$, グアノシン (dG), チミジン (dT) (RNA 中ではウリジン $(\mathrm{U})$ ), シトシン $(\mathrm{dC})$ のうち, イミド構造を有する $\mathrm{dT}$ （U）のみを選択的に認識して複合体を生成す る. ${ }^{7-13,15,24-28,34,35)}$ これは, dT のイミドプロトンが 引き抜かれて生じた $\mathrm{N}^{-}$と, 1 の亜鉛（II）イオン 間の配位結合と, $\mathrm{dT}$ の 2 つカルボニル酸素と cyclen 環のアミノプロトンとの間の水素結合によっ て安定化される. ${ }^{34,35)}$

筆者らは，まず多核亜鉛錯体による水溶液中での チミジン誘導体の選択的認識を, 核酸化学へ展開す ることにした。

4. 核酸の光損傷反応を制御する二核亜鉛錯体 細胞が紫外線の照射を受けると, 核酸に様々な光 損傷が起こる，その最も代表的な例が，隣接する 2 つのチミジンの間で進行する光 $[2+2]$ 付加環化反 応であり, $c i s-s y n$ 配置のシクロブタン型チミンダ イマー 15 を主生成物として与える。このような核 酸変異は DNA 複製エラーの原因となり, 細胞死や 突然変異を誘発する. ${ }^{36,37)}$ 筆者らは 14 の光 $[2+2]$ 付加環化反応が, 二核亜鉛錯体との安定な複合体 （16）生成によって阻害されると予想し，その仮説 が正しいことを証明した (Fig. 3). ${ }^{38)}$

ジヌクレオチド $\mathrm{d}(\mathrm{TpT})$ 14b 基質として用い て光反応を検討したところ, 二核錯体 4 及び 5 が 14b から 15bへの光反応を著しく阻害した. 14b と 二核亜鉛錯体の相互作用を $\mathrm{pH}$ 滴定, UV 滴定, 等 温カロリメトリーなどで解析した結果, 14b と 4 の 1 対 1 複合体 16 の解離定数 $K_{\mathrm{d}}$ は $\mathrm{pH} 7.4$ 及び $25^{\circ} \mathrm{C}$ で $0.4 \mu \mathrm{M}$ であり, $\mathrm{dT}$ と単核錯体 $3 \mathbf{a}$ の 1 対 1 複合 体 $\left(K_{\mathrm{d}}=0.4 \mathrm{mM}\right)$ よりも約 1000 倍熱力学的に安定 であることが分かった。 


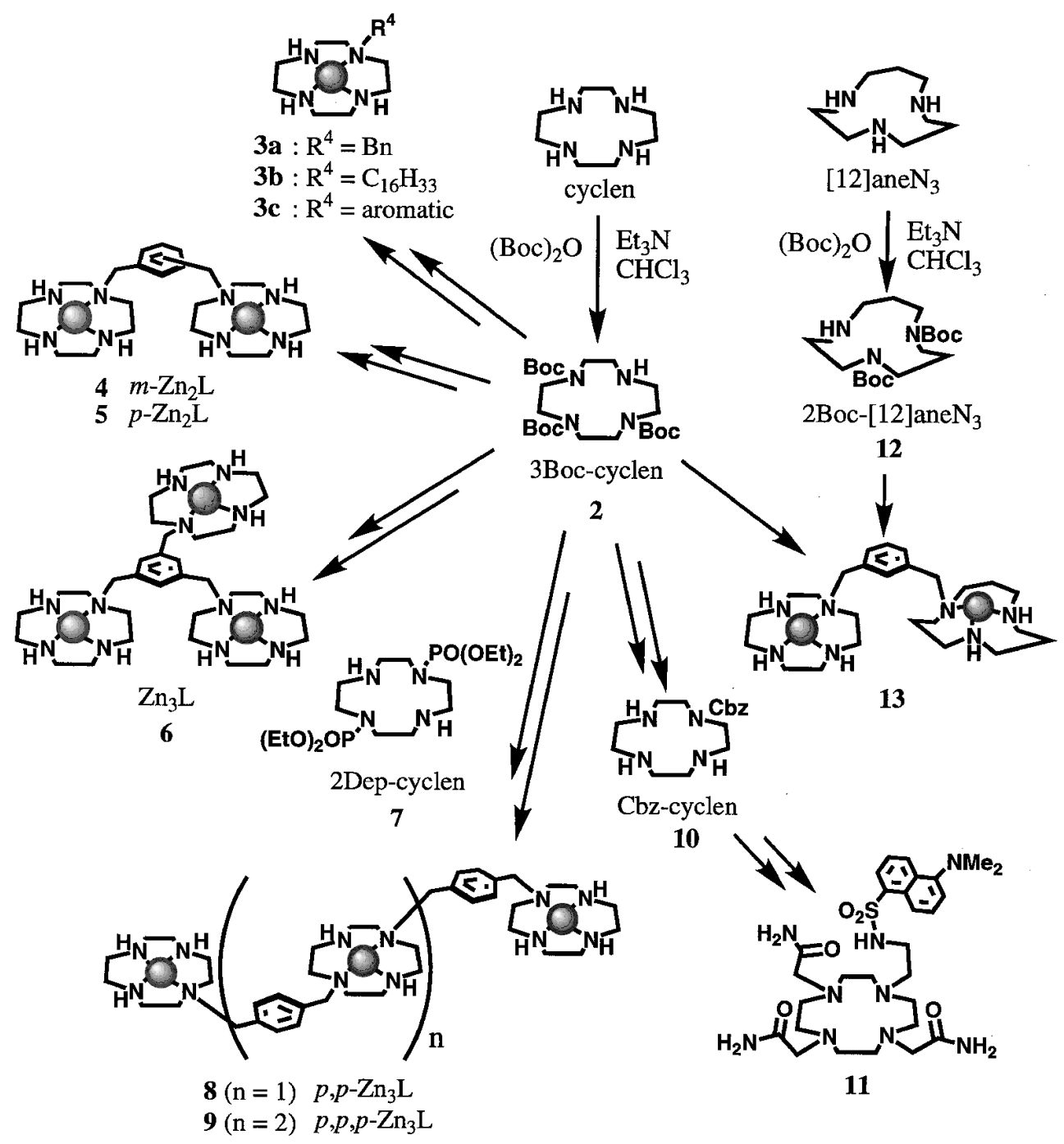

Fig. 2. Synthesis of Cyclen Derivatives and Their Metal Complexes

また，中性 $\mathrm{pD}$ 重水中の ${ }^{1} \mathrm{H}$ NMR 測定では， 14b と 16 が別々のシグナルを与えた。これは $14 \mathrm{~b} \rightleftarrows 16$ の平衡が遅く, 16 の寿命がミリ秒オーダーである ことを示唆した. 14b の光励起状態の寿命は一重項 状態でピコ秒オーダー, 三重項状態でナノ秒オー ダーであると推定されており, ${ }^{39)} \mathbf{1 6}$ の寿命の方が長 いと考えられる。したがって，16のように2つの チミジン基が約 8一10̊̊の距離に固定されたまま 16 の光励起状態が基底状態に戻ってしまうため, 光反応阻害が効率良く抑制されたと結論した（Fig. 3).

さらに, cis-syn シクロブタン型チミンダイマー 15b を合成して亜鉛錯体との相互作用を検討したと ころ，15b は単核錯体 3a と 1 対 1 複合体を，二核 錯体 4 とは 2 対 1 複合体を生成することが分かつ
た。これらの亜鉛錯体存在下で $\mathbf{1 5 b}$ に紫外線を照 射したところ，14bへの開裂反応が加速され，14b $(16) \rightleftarrows 15 b$ の平衡が開裂方向に片寄ることを見い 出した.

さらに $\mathrm{dT}$ のポリマー $($ poly $(\mathrm{dT}))$ の光反応を 行ったところ， 4 によって光 $[2+2]$ 付加環化反応 が阻害されること，4非存在下でいったん平衡に達 した後 4 を加えるとシクロブタンの光開裂反応が加 速されることが分かった (Fig. 4). 以上の現象は 亜鉛錯体の光反応制御剂としての可能性を示してお り, 核酸の光損傷を修復する触媒などへの展開も考 えられる。

5. チミジン及びチミジンリン酸化体に高選択的 なレセプターの開発と抗 HIV 薬への展開

後天性免疫不全症候群（AIDS）が深刻な社会問 


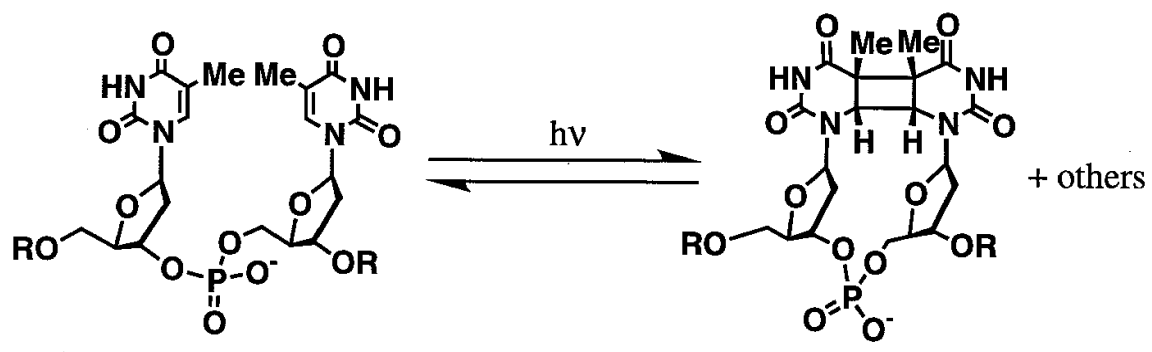

14a: $\mathrm{R}=$ oligonucleotide

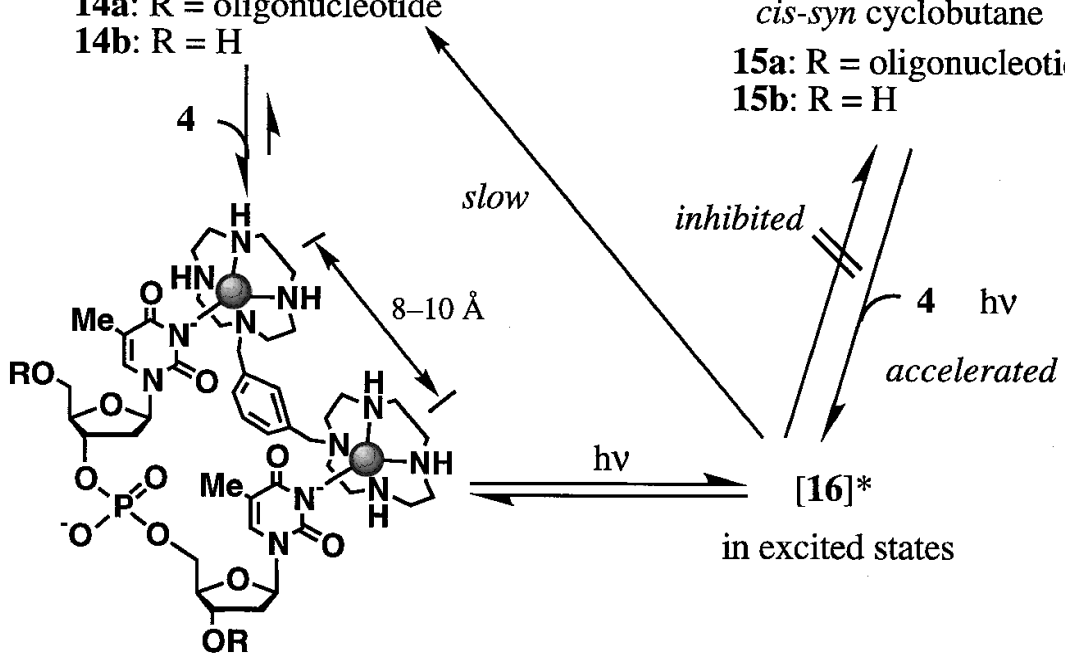

$1: 114-m-\mathrm{Zn}_{2} \mathrm{~L}$ complex

16

thermodynamically (indicated by $\mathrm{pH}, \mathrm{UV}$, and isothermal calorimetric titrations) and kinetically (shown by ${ }^{1} \mathrm{H}$ NMR) stable

Fig. 3. Efficient Inhibition of Photo $[2+2]$ cycloaddition of Thymidine Dimer by Dimeric $\mathrm{Zn}^{2+}$ Complexes

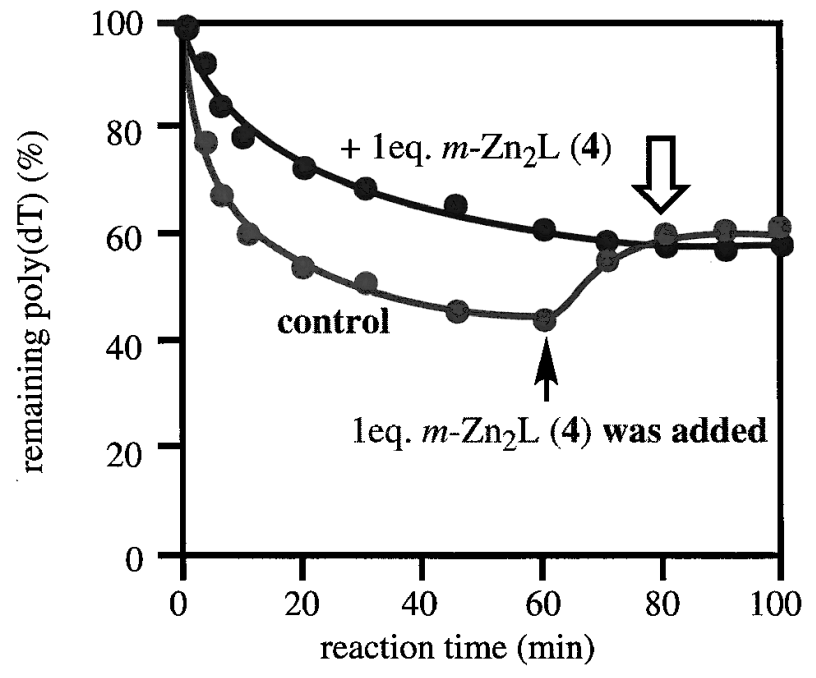

Fig. 4. Effect of $m-\mathrm{Zn}_{2} \mathrm{~L}(4)$ on the Photoreaction of $65 \mu \mathrm{M}$ Poly (dT) in $10 \mu \mathrm{M} \mathrm{NaH} \mathrm{PO}_{4}-\mathrm{Na}_{2} \mathrm{HPO}_{4}$ Buffer (pH 7.6 with $\left.I=0.1\left(\mathrm{NaNO}_{3}\right)\right)$ at $4^{\circ} \mathrm{C}$
題となっている，その治療は，主に AIDS の原因 ウイルスであるヒト免疫不全ウイルス HIV-1（human immunodeficiency virus-1） がターゲットとな つている。逆転写酵素阻害剂 2 剂（AZT（Zidovudine）など）と HIV プロテアーゼ阻害剤 1 剂（Indinavir など）の組み合わせによる 3 剂併用療法を 代表とする HAART (highly active antiretroviral therapy）が現在最も効果的な AIDS 治療法として 臨床的に行われている. ${ }^{40)}$

筆者らは dT の誘導体である AZT のキャリアー として，本来水溶性である $\mathrm{Zn}^{2+}$-cyclen に長鎖アル キル基を導入した脂溶性亜鉛錯体を開発した (Fig. 5). ${ }^{15)}$ 例えば炭素数 16 のアルキル基をもつ 3b は核酸塩基のうちチミジン誘導体を選択的に水 溶液から有機溶媒へ抽出する。特に AZT を中性 $\mathrm{pH}$ 水溶液から $90 \%$ 以上抽出し，これは AZT の脂 溶性が（AZT）--3b 複合体 $\mathbf{1 7}$ の脂溶性に反映した 


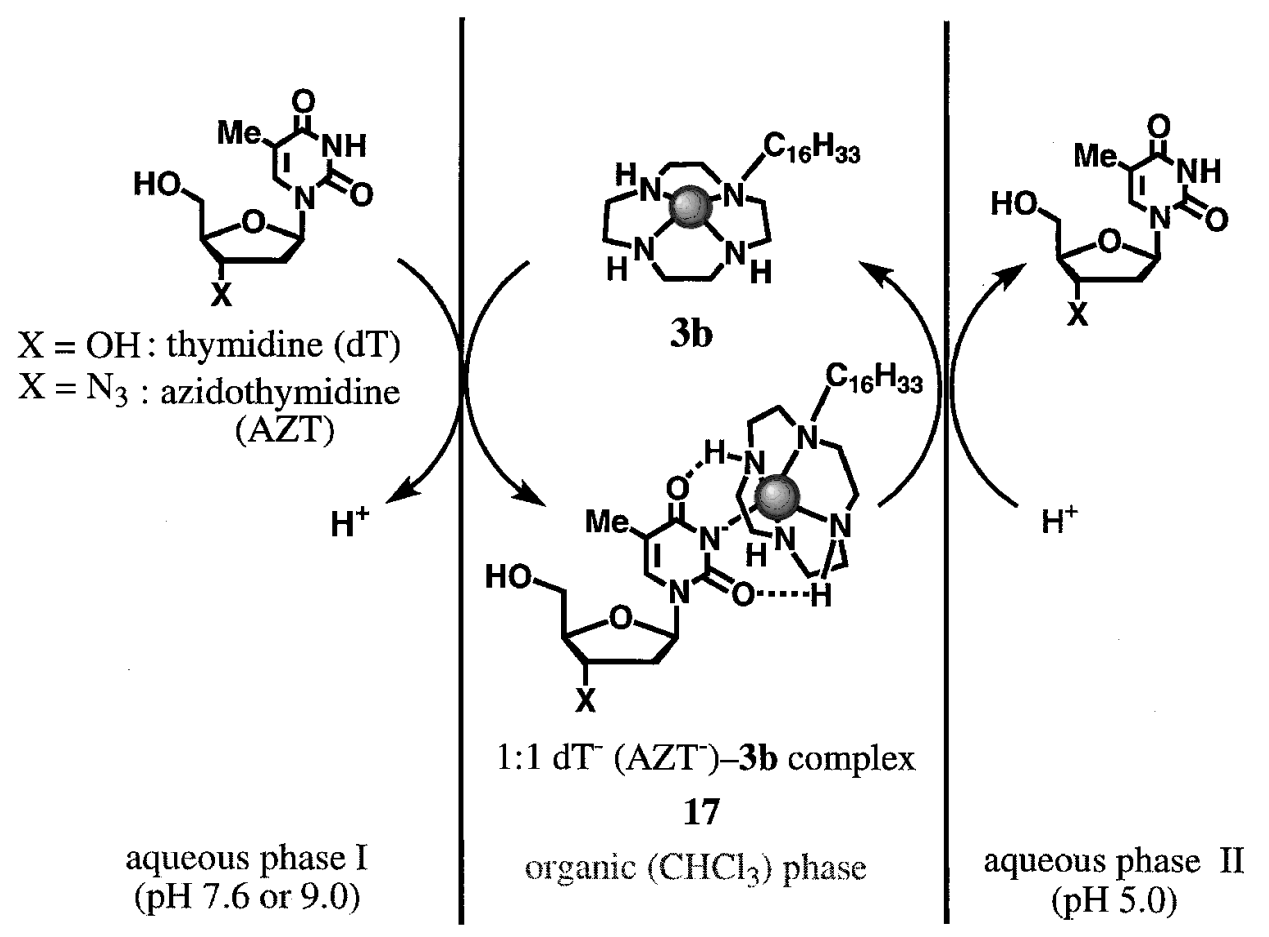

Fig. 5. Highly Selective Extraction and pH-Driven Transport of dT Nucleosides by Lipophilic Zinc(II) Complexes

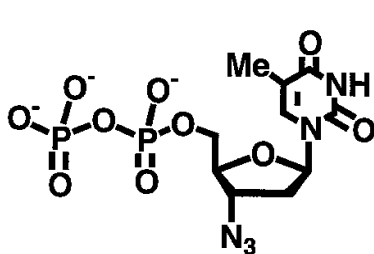

AZT diphosphate (AZTDP)

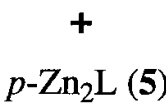

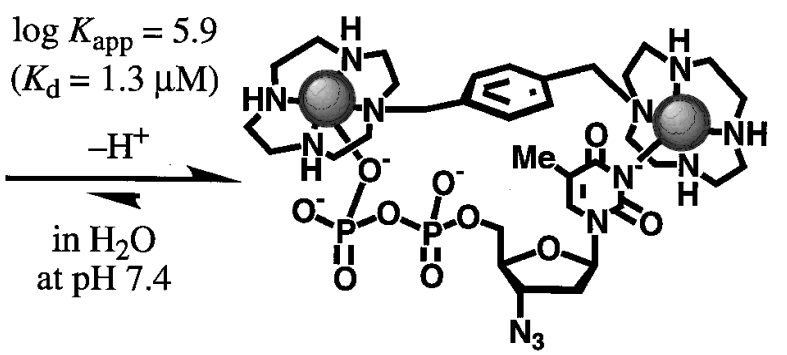

$1: 1(\text { AZTDP })^{4-}-5$ complex

18

thermodynamically and kinetically stable

Fig. 6. Highly Selective Recognition of AZT Diphosphate by $\mathrm{Zn}_{2} \mathrm{~L}$

ためと考えられた. さらに，3b が $\mathrm{dT}$ 誘導体の中 性水溶液層から酸性水溶液層への有機層を介した $\mathrm{pH}$ 駆動液膜輸送を行うことも報告した。

AZT はプロドラッグであり, 細胞内でキナーゼ による三段階のリン酸化を受けて AZT triphosphate (AZTTP) に変換され, HIV 逆転写酵素の基 質となる。 HIV の DNA に組み込まれた AZT はそ れ以降の DNA 合成を阻害する。 ${ }^{41,42)}$ そのため種々 の AZT や 2',3'-dideoxy-2', $3^{\prime}$-didehydrothymidine （d4T）リン酸化体の脂溶性誘導体がプロドラッグ

\section{として報告されてきた. ${ }^{43,44)}$}

それに対し，筆者らは二核亜鉛錯体が AZT リン 酸化体のイミド構造とリン酸ジニオンを協同的に認 識し, 直接細胞内へ導入するキャリアーとなりうる のではないかと考えた。実際に二核錯体 4 又は 5 と dT (U) MP, dT (U) DP, dT (U) TP, AZTMP, AZTDP などとの相互作用を検討すると, これらの 1 対 1 複 合体（例えば 18）は単核錯体 3a と d T (又は AZT), 3a と phenyl phosphate の複合体に比べて, 約 100-1000 倍熱力学的に安定であることが分かっ 
た（Fig. 6). ${ }^{45,46)}$ また, 18 は $\mathbf{1 6}$ と同様, ${ }^{1} \mathrm{H}$ NMR (400 MHz) の時間スケールで速度論的にも安定で ある、さらに筆者らは長鎖アルキル基を導入した脂 溶性二核錯体を合成し，非イオン性界面活性剂存在 下で AZT リン酸化体を 4 に匹敵する強さで認識す ることを見い出した. ${ }^{47)}$ これらの亜鉛錯体は新たな ドラッグデリバリーシステムとして期待できる. ${ }^{48)}$

また二核亜鉛錯体 4 は, HIV が細胞に感染に必 要なセカンドレセプター（ケモカインレセプター） と HIV の相互作用を阻害する, 新しいタイプの抗 HIV 薬であることが報告されている. ${ }^{49-55)} さ{ }^{5}$ さに 直列型三核亜鉛錯体 7 が HIV の Tat 蛋白と TAR の相互作用を阻害することも明らかになった. ${ }^{27)} し$ たがって, 多核亜鉛錯体は HIV の増殖サイクルの 様々なポイントを阻害する全く新しい薬剤として期 待される.

\section{6. 三次元的自己集積体の構築}

上記のように，亜鉛錯体が $\mathrm{dT}$ のイミド基を認識 すること，多核亜鉛錯体とポリアニオン性化合物が 中性 $\mathrm{pH}$ 水溶液中で熱力学的及び速度論的に安定な 複合体を生成するという知見から, 筆者らは新しい 三次元的自己集積体の化学を展開した.
まず三核亜鉛（II）錯体 $\left(\mathrm{Zn}_{3} \mathrm{~L}\right) \mathbf{6}$ と 6 員環トリ アミド化合物であるシアヌル酸（CA）との水溶液 中における相互作用を検討したところ, pH 6 以上 で 2 分子の 6 が 3 分子の $\mathrm{CA}$ ジアニオン $\left(\mathrm{CA}^{2-}\right)$ を挟んだサンドウィッチ型超分子 19 が生成するこ とが分かった (Fig. 7). ${ }^{56)}$

さらに，6とCAを 1 対 1 で溶かした水溶液の $\mathrm{pH}$ を 11 に合わせた水溶液から，無色プリズム晶 が析出した。 X 線結晶構造解析の結果, 意外にも これは，6 と CAトリアニオン $\left(\mathrm{CA}^{3-}\right)$ が 4 対 4 で集積したかご型超分子 $\mathbf{2 0}$ であることが判明した.

12 個の巠鉛（II）イオンをもち，2.4一-2.5ナノメー トルの大きさをもつ超分子である.

20 は内部空間を有しているので, 当初我々は 20 が水溶液中で生成していることを期待したが，検討 の結果, 20 は結晶中や DMSO 中のみで安定であ り，水溶液中では 2 対 3 集積体 19 として存在して いることが分かった。これは，CAの 3 つのイミド プロトンの $\mathrm{p} K_{\mathrm{a}}$ が， 6.9，10.9>12 であり， 3 つめの イミドプロトンの $\mathrm{p} K_{\mathrm{a}}$ が高いためであると考えら れた。

水溶液中において $\mathbf{2 0}$ のよう超分子が構築でき

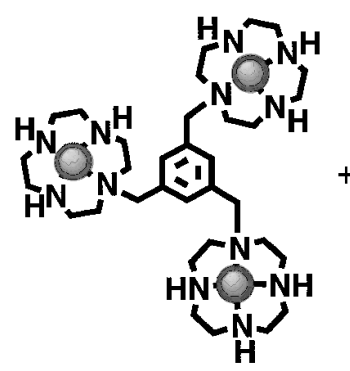

6

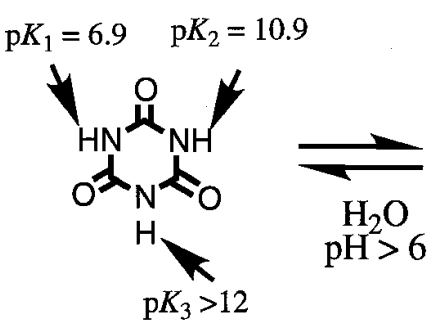

Cyanuric acid (CA)
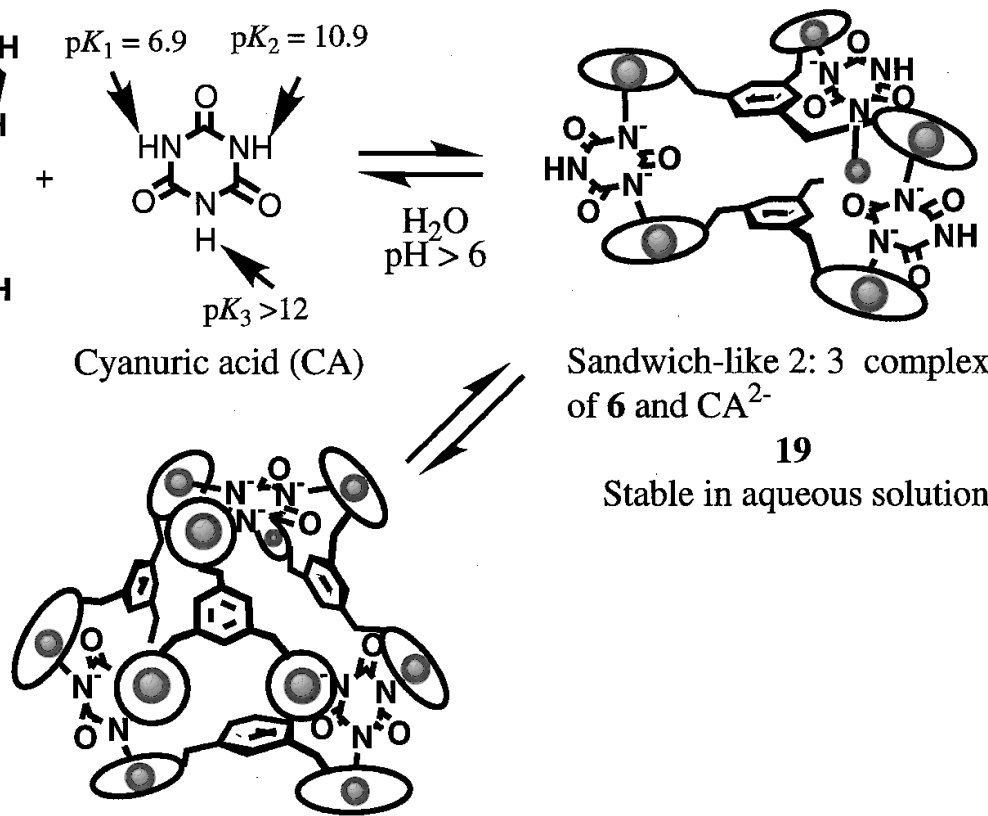

Sandwich-like 2: 3 complex of 6 and $\mathrm{CA}^{2-}$

\section{9}

Stable in aqueous solution

Cage-like 4: 4 complex of 6 and $\mathrm{CA}^{3-}$

Stable in crystals and in DMSO

Fig. 7. Supramolecular Complexes Formed by Trimeric $\mathrm{Zn}^{2+}$ Complex and Cyanuric Acid in Aqueous Solution 
れば，その内部空間が有機化合物の認識場になり得 ると考えた。そこで筆者らはトリチオシアヌル酸 （TCA）に注目した（Fig. 8). TCA の $\mathrm{p} K_{\mathrm{a}}$ （5.1， 8.2, 11.7) はCAのそれよりも低く，水溶液中で卜 リアニオン $\left(\mathrm{TCA}^{3-}\right)$ 発生に有利であると考えら れる. また 3 つの硫黄原子上に局在化したアニオン $\left(\mathrm{S}^{-}\right)$が亜鉛（II）イオンに配位することによって, 20 と同様の三次元的超分子が生成すると予想した.

実際に 6 と TCA の 1 対 1 水溶液の $\mathrm{pH}$ を 8 から 9 に調整し, 徐々に濃縮していくと無色プリズム晶 が得られた。 X 線結晶構造解析の結果, 6 と TCA トリアニオン体（ $\mathrm{TCA}^{3-}$ ) の $\mathrm{S}^{-}-\mathrm{Zn}^{2+}$ 配位結に基 づく $4: 4$ 集積体 20 であることが明らかになった (Fig. 8b). 57-59)

一度単離された 21 を水溶液に溶かして ${ }^{1} \mathrm{H}$ NMR を測定すると，いくつかの分子種に由来するとみら れるシグナルが観測された。ここに3-(trimethylsilyl) propionic-2,2,3,3- $d_{4}$ acid (TSP) などの化合
物を加えたところ, ${ }^{1} \mathrm{H}$ シグナルは 1 種類になつ た。さらに TSP のシグナルは $-2.0 \mathrm{ppm}$ の高磁場 に観測され，21 の内部空間に包接され，21 を安定 化していることが考えられた. 内部空間へのゲスト 分子の取り込みは，アダマンタン包接体の X 線結 晶構造解析によって証明された（Fig. 8c.）。種々の 測定結果から，21 はゲストのサイズと疎水性を認 識して包接し, 単一の超分子として熱力学的, 速度 論的に安定に生成していることが示唆された。また ゲスト分子の放出, 交換が可能であるので, 水に溶 けにくい薬物などを水に可溶化し, ターゲット細胞 に送り込む薬物輸送カプセルとしても期待できる.

\section{7. 光応答性センサーの設計と合成}

筆者らは，先に亜鉛イオン蛍光センサー 22 を報 告した。 22 は Fig. 10a に示すように， $\mathrm{Zn}^{2+}$ 及び $\mathrm{Cd}^{2+}$ に対して蛍光応答を示す。これは, 22 の $\mathrm{Zn}^{2+}$ 錯体 23 (又は $\mathrm{Cd}^{2+}$ 錯体) のスルホンアミド プロトンが, 中性 $\mathrm{pH}$ 水溶液中で脱プロトン化され

(a)

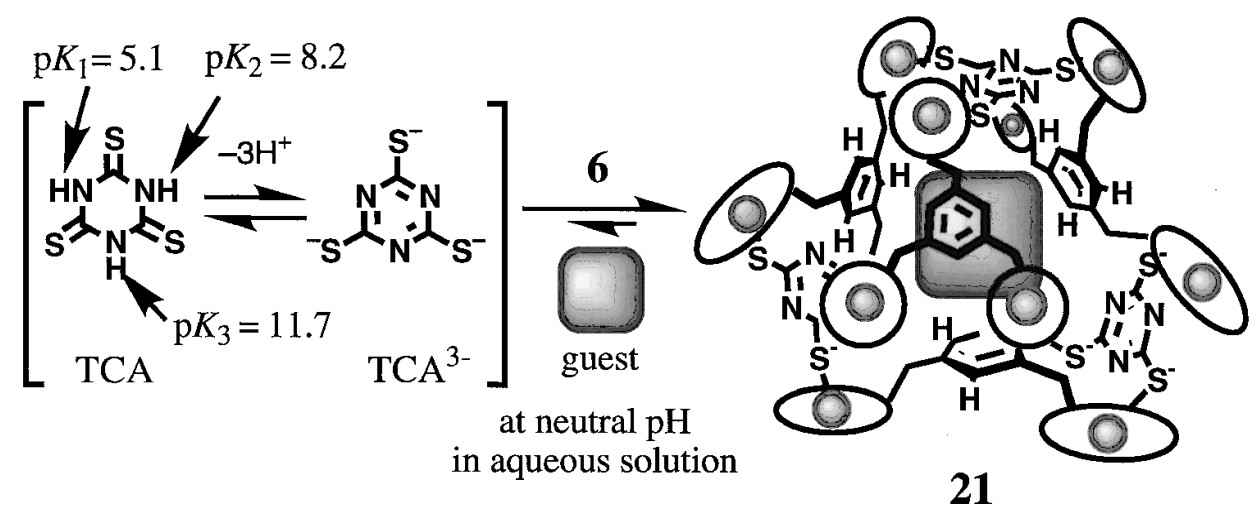

(b)

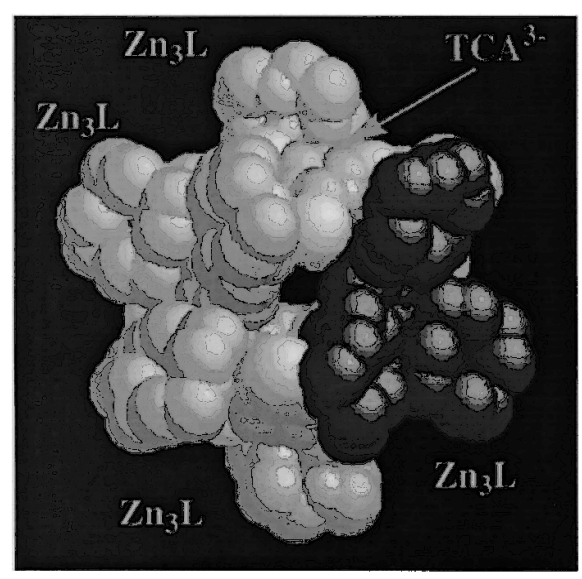

(c)

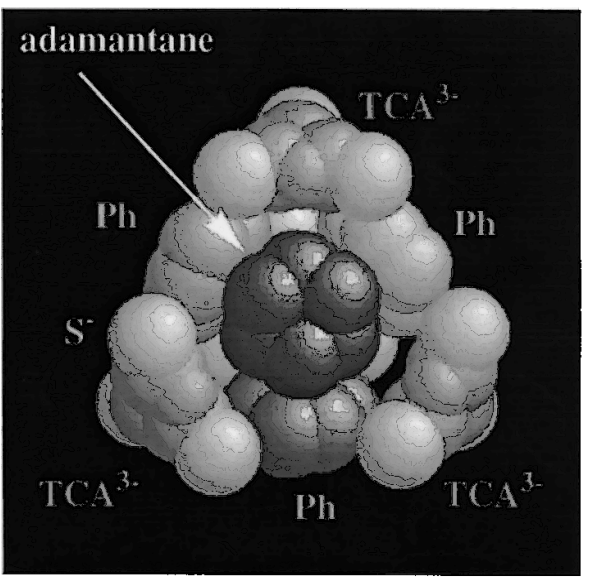

Fig. 8. (a) A supramolecular Capsule (21) Formed by $\mathrm{Zn}_{3} \mathrm{~L}$ (6) and Trithiocyanuric Acid in Aqueous Solution at Neutral pH, (b) Space-filling drawing of Cyrstal Structure of 21. (c) Inner Space of 21-Adamantane Complex 


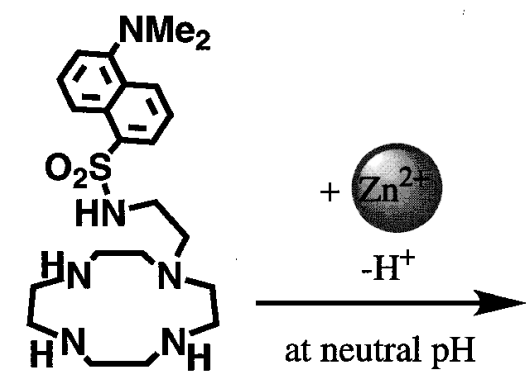

21

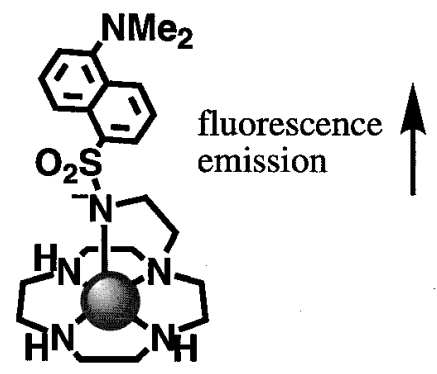

22

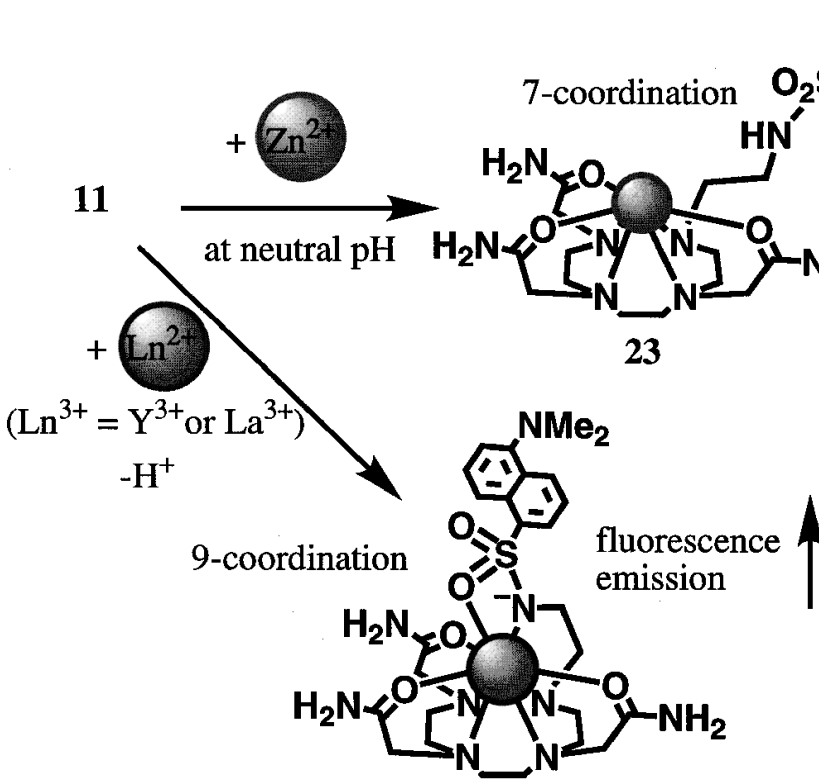

24

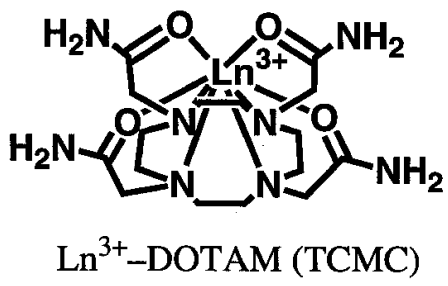

25

Fig. 9. Design of a New Metal Sensor

るためである (Fig. 9.).60-63)一方， cyclen にアミ ド基（例えば 26）やカルボキシレート基を導入す るとランタノイドと錯体を生成することが報告され ている. ${ }^{64,65)}$ そこで筆者らは，ランタノイドイオン に対して選択的に応答する蛍光センサーとして, 22 にアセトアミド基を導入した 11 合成した (Fig. 1). 31) 11 の種々の金属イオンに対する蛍光変 化を測定したところ，興味深いことに $\mathrm{Zn}^{2+}$ や $\mathrm{Cd}^{2+}$ に対して全く応答せず， $\mathrm{Y}^{3+}$ 及び $\mathrm{La}^{3+}$ を加 えると蛍光強度が増大することが見い出された (Fig. 10). pH 滴定，X 線結晶構造解析などにより, 11 の亜鉛錯体 24 では, サイクレンの 4 つの窒素原 子と側鎖の 3 つのアミド酸素が亜鉛イオンに配位 （7配位）するために亜鉛イオン（一般的には 4-6 配位）のルイス酸性がマスクされ，ダンシルアミド
のプロトンが脱プロトン化されていないと推定され た。一方, $\mathrm{Y}^{3+} や \mathrm{La}^{3+}$ などランタノイドイオンは 7-9 の配位数が可能であるため，側鎖のアミド酸 素が配位しても脱プロトン化されたダンシルアミド アニオンが $\mathrm{Y}^{3+}$ 又は $\mathrm{La}^{3+}$ に配位でき，25 が生成 するものと結論された.

11 に関するもう 1 つの発見は，その蛍光強度が 金属イオン非存在下, 中性付近からアルカリ性で増 大することであった（Fig. 11）. Figure 11 のグラフ の曲線から, 11 のダンシルアミドプロトンの $\mathrm{p} K_{\mathrm{a}}$ 值が $8.8 \pm 0.2$ と求められたが，この值は $\mathrm{pH}$ 滴定, UV 測定， ${ }^{1} \mathrm{H}$ NMR によって決定された基底状態の $\mathrm{p} K_{\mathrm{a}}$ 值 10.8 に比べて 2 ユニット小さい. したがっ て，8.8土0.2 は， 11 の光励起状態における $\mathrm{p} K_{\mathrm{a}}$ 值 に相当すると考えられた。同位体効果の測定結果, 
(a)

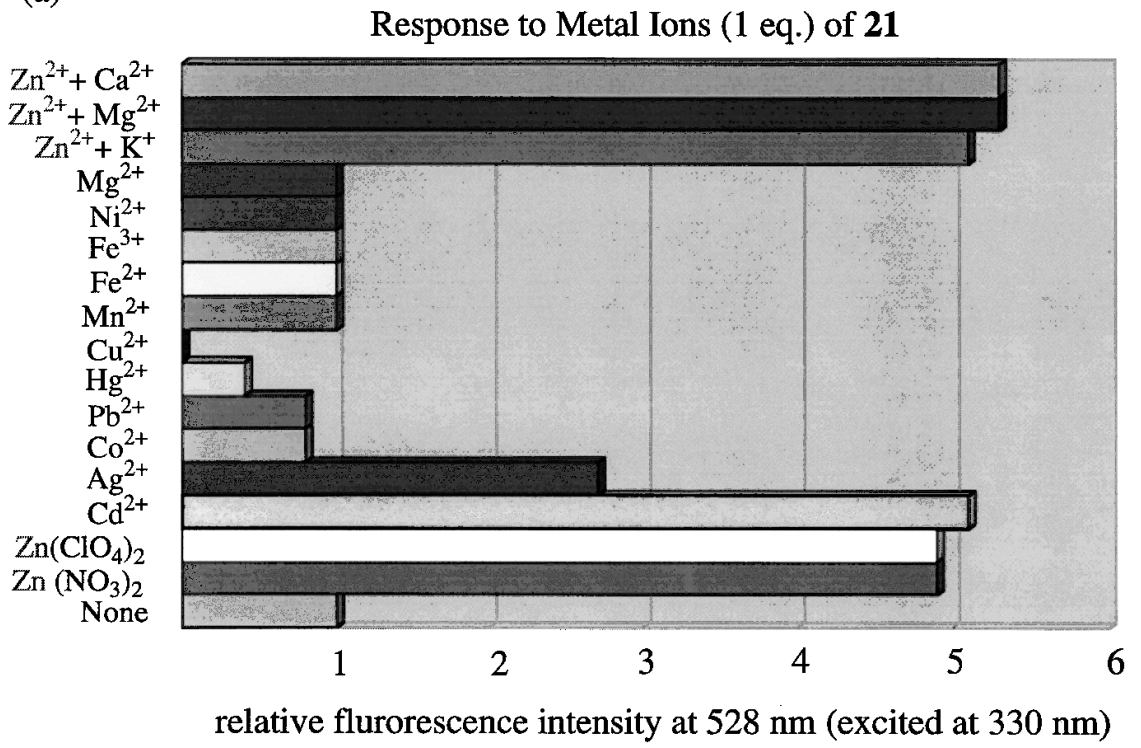

(b)

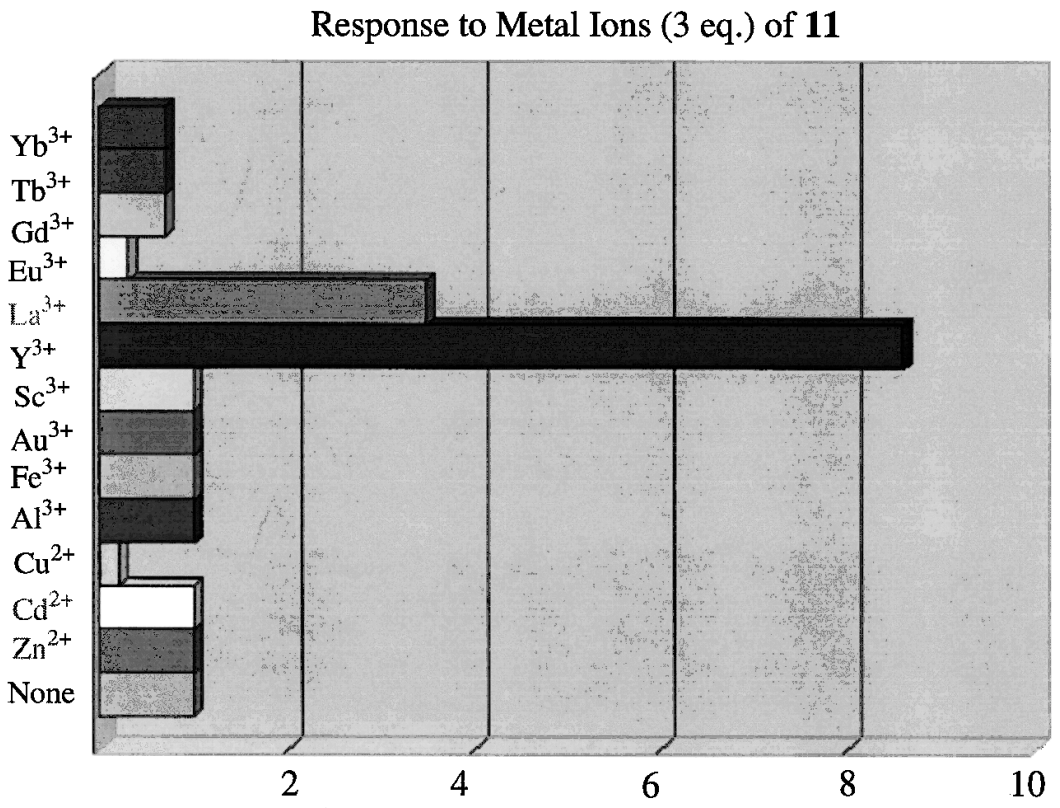

relative flurorescence intensity at $520 \mathrm{~nm}$ (excited at $335 \mathrm{~nm}$ )

Fig. 10. Comparison of Fluorescent Response of $\mathbf{2 2}$ (a) and 11(b) to Various Metal Ions at pH $7.4(10 \mu \mathrm{M}$ HEPES with $I=0.1$ $\left.\left(\mathrm{NaNO}_{3}\right)\right)$ and $25^{\circ} \mathrm{C}$

11 のダンシルアミドプロトンは，3つの側鎖のカル ボニル酸素と相互作用することにより, 光励起状態 においてその酸性度が増しているものと結論した。 このように基本的かつ非常に興味深い物理学的現象 が発見されたのは驚きであり, 今後蛍光試薬のデザ インをする上で貴重な知見である。

\section{8. おわりに}

水溶液中の有機化学は, 地球環境への配慮だけで
なく, 水溶性基質を用いる合成化学, 分析化学の必 要性, 生体への適応からも重要であり, 大きな展開 が望まれる. 今後も有機化学, 無機化学的合成手 法, 分析化学, 物理化学的測定などを組み合わせな がら，金属錯体の特徵を生かした水溶液中の超分子 化学を発展させたい.

謝辞本研究の遂行に際して, 終始暖かいご指 


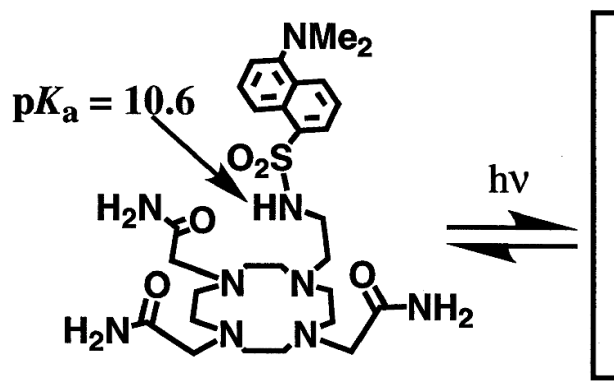

ground state

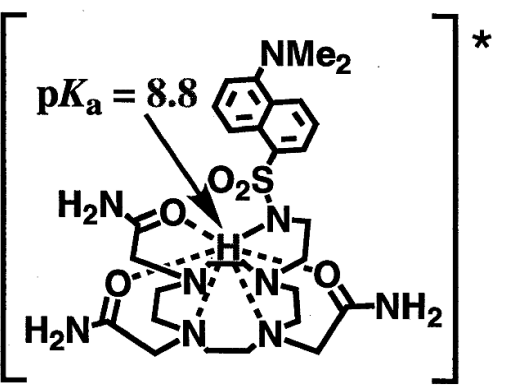

excited state

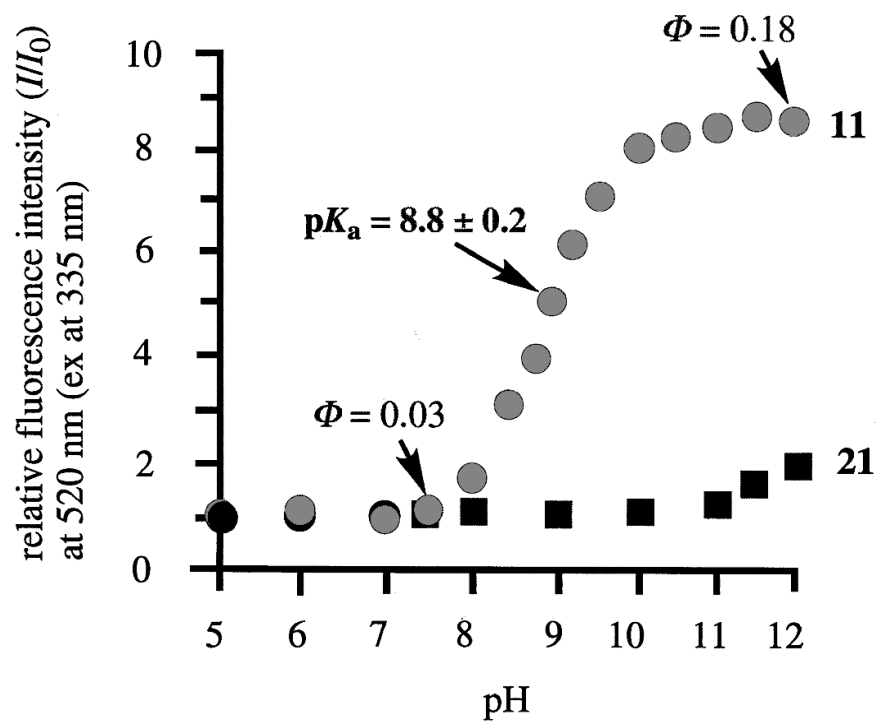

Fig. 11. pH-Dependent Change of Fluorescence Spectra of 11 (circle) and 22 (square)

導を賜りました広島大学医学部，木村榮一教授にこ の場をお借りして深く感謝申し上げます。またX 線結晶構造解析を行っていただいた理学電機 X 線 研究所, 城 始勇博士, 物理化学的測定をご指導く ださいました小池透教授（広島大学大学院医歯薬学 総合研究科), 共同研究者の本田裕介修士, 杉村智 都代学士, 川谷宏樹修士, 木下恵美子博士（広島大 学大学院医歯薬学総合研究科) 他, 木村研究室の卒 業生並びに在校生の皆様に篤く感謝いたします。

\section{REFERENCES}

1) Lehn J.-M., "Supramolecular Chemistry: Concepts and Perspectives," VCH, Weinheim, 1995.

2) Whitesides G. M., Mathias J. P., Seto C. T., Acc. Chem. Res., 28, 37-44 (1995).

3) Philip D., Stoddart J. F., Angew. Chem. 108,
1242-1286 (1996); Angew. Chem. Int. Ed. Engl. 35, 1155-1196 (1996).

4) Piguet C., Bernardinelli G., Hopfgartner G., Chem. Rev., 97, 2005-2062 (1997).

5) Holliday B. J., Mirkin C. A., Angew. Chem. Int. Ed. Engl., 40, 2022-2043 (2001).

6) Prins L. J., Reinhoudt D. N., Timmerman P., Angew. Chem. Int. Ed. Engl., 40, 2382-2426 (2001).

7) Kimura E. "Progress in Inorganic Chemistry,” ed. by Karlin K. D., John Wiley \& Sons, New York, 1994, pp. 443-491.

8) Kimura E., Koike T., Shionoya M., "Structure and Bonding: Metal Site in Proteins and Models,' ed. by Sadler P. J., Springer, Berlin, 1997, pp. 1-28.

9) Kimura E., Koike T., J. Chem. Soc. Chem. Commun., 1495-1500 (1998).

10) Kimura E., Koike T., "Bioinorganic Cataly- 
sis," eds. by Reedjik J., Bouwman E., Marcel Dekker Inc., New York, 1999, pp. 33-54.

11) Kimura E., Kikuta E., J. Biol. Inorg. Chem., 5, 139-155 (2000).

12) Kimura E., Curr. Op. Chem. Biol., 4, 207-213 (2000) .

13) Kimura E., Acc. Chem. Res., 34, 171-179 (2001).

14) Kimura E., Aoki S., Koike T., Shiro M., J. Am. Chem. Soc., 119, 3068-3076 (1997).

15) Aoki S., Honda Y., Kimura E., J. Am. Chem. Soc., 120, 10018-10026 (1998).

16) Koike T., Gotoh T., Aoki S., Kimura E., Shiro M., Inorg. Chim. Acta, 270, 424-432 (1998) .

17) Kimura E., Gotoh T., Koike T., Shiro M., J. Am. Chem. Soc., 121, 1267-1274 (1999).

18) Kikuta E., Matsubara R., Katsube N., Koike T., Kimura E., J. Inorg. Biochem., 82, 269249 (2000).

19) Aoki S., Iwaida K., Hanamoto N., Shiro M., Kimura E., J. Am. Chem. Soc., 124, 52565257 (2002).

20) Kimura E., Gotoh T., Aoki S., Shiro M., Inorg. Chem. (in press).

21) Aoki S., Kaido S., Fujioka H., Kimura E., Shiro M. (submitted).

22) Subat M., König B., Synthesis, 1818-1825 (2001) .

23) Dumont A., Jacques V., Desterux J. F., Tetrahedron Lett., 35, 3707-3710 (1994).

24) Kikuta E., Murata M., Katsube N., Koike T., Kimura E., J. Am. Chem. Soc., 121, 54265436 (1999).

25) Kimura E., Katsube N., Koike T., Shiro M., Aoki S., Supramol. Chem., 14, 95-102 (2002).

26) Kimura E., Kikuchi M., Kitamura H., Koike T., Chem. Eur. J., 5, 3113-3123 (1999).

27) Kikuta E., Aoki S., Kimura E., J. Am. Chem. Soc., 123, 7911-7912 (2001).

28) Kikuta E., Aoki S., Kimura E., J. Inorg. Chem., 7, 473-482 (2002).

29) Aoki S., Zulkefeli M., Shiro M., Kimura E., Proc. Natl. Acad. Sci. U.S.A., 99, 4894-4899 (2002).

30) Aoki S., Sougon T., Kimura E. (unpublished results).

31) Aoki S., Kawatani H., Gotoh T., Kimura E.,
J. Am. Chem. Soc., 123, 1123-1132 (2001).

32) Bu X.-H., Lu S.-L., Zhang R.-H., Liao D.Z., Aoki S., Clifford T., Kimura E., Inorg. Chim. Acta, 298, 50-56 (2000).

33) Tatsuta M., Aoki S., Kimura E. (unpublished results).

34) Shionoya M., Kimura E., Shiro M., J. Am. Chem. Soc., 115, 6730-6737 (1993).

35) Shionoya M., Kimura E., Shiro M., J. Am. Chem. Soc., 116, 3848-3859 (1994).

36) Wang S. Y., "Photochemistry and Photobiology of Nucleic Acids," Academic Press, New York, 1976.

37) Friedberg E. C., Walker G. C., Siede W., "DNA Repair and Mutagenesis," ASM Press, Washington, DC, 1995.

38) Aoki S., Sugimura C., Kimura E., J. Am. Chem. Soc., 120, 10094-10102 (1998).

39) Sancar A., Adv. Electron Transfer Chem., 2, 215-272 (1992).

40) Bala M., Molecular Medicine, 36, 1034-1043 (1999).

41) Furman P. A., Fyfe J. A., St. Clair M. H., Weinhold K., Rideout J. L., Freeman G. A., Lehrman S. N., Bolognesi D. P., Broder S., Mitsuya H., Barry D. W., Proc. Natl. Acad. Sci. U.S.A., 83, 8333-8337 (1986).

42) Gao W.-Y., Agbaria R., Driscoll J. S., Mitsuya H., J. Biol. Chem., 269, 12633-12638 (1994).

43) Rosowski A., Fu H., Pai N., Mellors J., Richman D. D., Hostetler K. Y., J. Med. Chem., 40, 2482-2490 (1997).

44) Magnani M., Casabianca A., Fraternale A., Brandi G., Gessani S., Williams R., Giovine M., Damonte G., De Flora A., Benatti U., Proc. Natl. Acad. Sci. U.S.A., 93, 4403-4408 (1996).

45) Aoki S., Kimura E., J. Am. Chem. Soc., 122, 4542-4548 (2000).

46) Aoki S., Kimura E., Rev. Mol. Biotech., 90, 129-155 (2002).

47) Aoki S., Honda Y., Kimura E. (unpublished results).

48) Mirchandani H., Chien Y. W., Internatl. J. Pharmaceut., 95, 1-21 (1993).

49) Inouye Y., Kanamori T., Yoshida T., Bu X., Shionoya M., Koike T., Kimura E., Biol. Pharm. Bull., 17, 243-250 (1994). 
50) Kimura E., Koike T., Inouye Y., "Perspect. Bioinorg. Chem,", eds. by Hay R. W., Dilworth J. R., Nolan, K. B., JAI Press Inc., Stanford, 1999, pp. 145-164.

51) De Clercq E., J. Med. Chem., 38, 2491-2517 (1995).

52) Gerlach L. O., Skerlj R. T., Bridger G. J., Schwartz T. W., J. Biol. Chem., 276, 1415314160 (2001).

53) De Clercq E., Mol. Pharm., 57, 833-839 (2001).

54) De Clercq E., Curr. Med. Chem., 8, 15431572 (2001).

55) Tamamura N., Yakugaku Zasshi, 781, 781792 (2001).

56) Aoki S., Shiro M., Koike T., Kimura E., J. Am. Chem. Soc., 122, 576-584 (2000).

57) Aoki S., Shiro M., Kimura E., Chem. Eur. J., 8, 929-939 (2002).
58) Aoki S., J. Synth. Org. Chem., Jpn, 59, 410411 (2001).

59) Aoki S., Kimura E., Kagaku to Kyoiku, 50, 102-105 (2002).

60) Koike T., Watanabe T., Aoki S., Kimura E., Shiro M., J. Am. Chem. Soc., 118, 1269612703 (1996).

61) Kimura E., S. Afr. J. Chem., 50, 240-248 (1997).

62) Kimura E., Koike T., Chem. Soc. Rev., 27, 179-184 (1998).

63) Kimura E., Aoki S., BioMetals, 14, 191-204 (2001).

64) Amin S., Morrow J. R., Lake C. H., Chuyrchill M. R., Angew. Chem. Int. Ed. Engl., 33, 773-775 (1995) .

65) Amin S., Voss D. A., Horrocks, Jr. W. D., Lake C. H., Churchill M. R., Morrow J. R., Inorg. Chem., 33, 3294-3300 (1994). 